\title{
AIV-22 虚血性心疾患の合併症に対する外科治療
}

\begin{tabular}{|c|c|c|c|c|c|c|c|}
\hline \multirow[b]{2}{*}{ 田野井 } & \multicolumn{7}{|c|}{ 日本大学 第 2 外科 } \\
\hline & 均 & 昆 & 晃 & 山崎 & 昭 & 宮本 & 晃 \\
\hline 岡崎 & 俊典 & 北村 & 信三 & 川野 & 幸志 & 萩原 & 秀男 \\
\hline 高橋 & 薫 & 陸川 & 秀智 & 名取 & 宏 & 新野 & 成隆 \\
\hline & & 折目 & 紀彦 & 瀬在 & 幸安 & & \\
\hline
\end{tabular}

心筋保護法の発達と補助循環法の普及により, 虚血性 心疾患に対する外科的治療は，より高令な症例，または 種々の合併症を有する症例を経験する機会が多くなって きている.

1968 年 5 月から 1983 年 3 月までK，われわれの教

表 1 Preoperative Complication

\begin{tabular}{|c|c|}
\hline Cardiac Failure & 36 \\
\hline Arrhythmias & 44 \\
\hline LVA & 37 \\
\hline LVFA & 1 \\
\hline LV Rupture & 1 \\
\hline VSP & 3 \\
\hline MR & 11 \\
\hline MS & 2 \\
\hline TR & 2 \\
\hline AR & 1 \\
\hline ASR & 1 \\
\hline ASO & 3 \\
\hline PM Implantation & 3 \\
\hline IHSS & 1 \\
\hline AAA & 4 \\
\hline AAIS & 1 \\
\hline Hypertension & 28 \\
\hline Respiratory Dysfunction & 22 \\
\hline Renal Dysfunction & 18 \\
\hline Cerebral Bleeding & 1 \\
\hline Cerebral Infarction & 5 \\
\hline Cerebral Atrophy & 4 \\
\hline Hemiplegia & 2 \\
\hline $\mathrm{DM}$ & 16 \\
\hline Banti's Syndtome & 1 \\
\hline Behcet's Disease & 1 \\
\hline MCLS & 1 \\
\hline Burger Disease & 1 \\
\hline Lung Tuberculosis & 4 \\
\hline \multirow[t]{2}{*}{ Hyperlipemia } & 1 \\
\hline & $\begin{array}{r}253 / 210 \\
(120.5 \%)\end{array}$ \\
\hline
\end{tabular}

室で経験した 210 症例について報告する. 術前の 臨床 検查上見出された主な合併症は, 心不全, 不整脈, 左室 瘤弁疾患, 高血圧症, 糖尿病, 腎機能障害, 呼吸機能障 害, 脳血管障害である (表 1 ).

表 2 Preoperative Complication (-)

\begin{tabular}{lc}
\hline 11 cases & Male 66, Female 10 \\
Death & 5 cases \\
Immediate causes of death & \\
Intestinal Bleeding & 1 \\
Agranulocytosis & 2 \\
Mediastinitis & 1 \\
Fluminant Hepatitis & 1 \\
\hline
\end{tabular}

表 3 Reconstruction Surgery

$\begin{array}{cr}\text { 0-CABG + Infarctomy } & 1 \\ \text { Patch Graft } & 1 \\ \text { LVA } & 6 \\ \text { LVA+Closure of VSP } & 3 \\ \text { 1-CABG + LVA } & 13 \\ \text { LVFA } & 2 \\ \text { AVR } & 2 \\ \text { MVR } & 3 \\ \text { AAA } & 1 \\ \text { 2-CABG + LVA } & 11 \\ \text { LVA+AAA } & 3 \\ \text { MVR+TAP } & 1 \\ \text { MVR } & 7 \\ \text { LVA } & 6 \\ \text { MVR } & 1 \\ \text { MVR +TVR } & 2 \\ \text { Iliofemoral bypass } & 1 \\ \text { MVR } & 1 \\ \text { 4-CABG + LVA } & 1\end{array}$

LVA: LV Aneurysmectomy

LVFA: LV False Aneurysmectomy

AAA: Abdominal Aortic Aneurysmectomy

TAP: Tricuspid Valvular Annuloplasty 

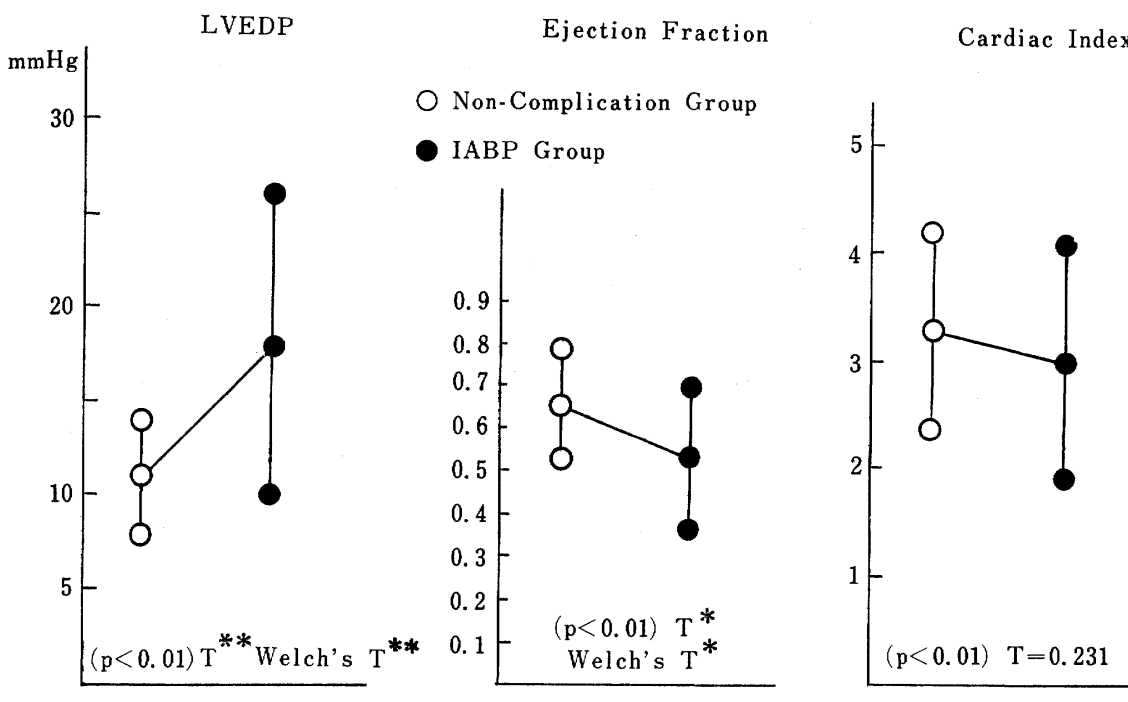

図 1

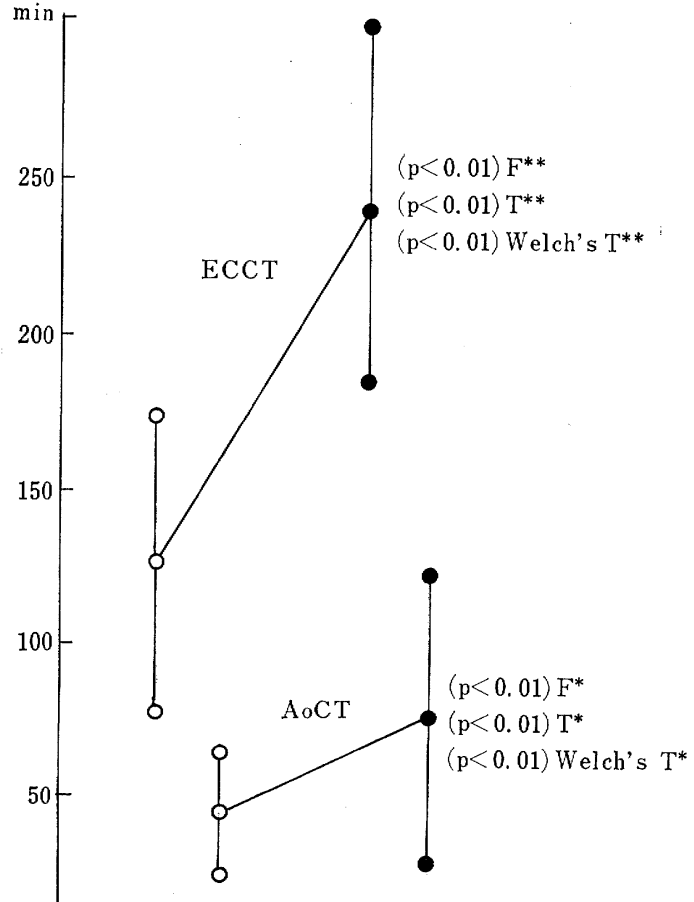

Non-Complication Group IABP Group ECCT:Extracorporal Circulation Time AoCT:Aorta Clamping Time

図 2
210 症例中に術前合併症のなかった症例が 76 例あり， このうち 5 症例が術後死亡しているが，直接死因を見る 之, 消化管出血 1 例, 顆粒球減少症 2 例, 縦隔炎 1 例, 激症肝炎 1 例で，5症例ともに心因性以外の原因で死亡 している (表 2).

CABG と合併症の同時手術例は 55 症例あり, 左室瘤 切除 31 例, 弁置換 17 例, 腹部大動脈瘤切除 4 例を経 験している (表 3 ).

高令者の虚血性心疾患の場合, 血管系障害は全身性の ものであり，脳血管性障害を合併していることを考慮し なくてはならないまた糖尿病，高血圧症などの risk factor が加わると, 術後に意識障害, 低拍出量症候群, 腎機能障害などの術後合併症を和こし易くなる。

われわれの教室では高令者（60 才以上）または，脳 血管系障害の既往のある 症例には CT scan などの検査 を行い，脳血管系障害の程度を十分に検討し，手術適応 を決めている。 また手術施行に際しては, 膜型人工肺を 使用し，体外循環時間の短縮に極力努めているが，脳梗 塞, 脳内出血などの既往があると, 術後意識障害, 運動 機能障害は増強し, 呼吸機能障害を併発して来る確率が 高くなるため，なお検討を要すると考えている.

$\mathrm{CABG}$ と腹部大動脈瘤の同時手術は, $\mathrm{CABG}$ 施行後, 体外循環の再加温時に, 開腹し大動脈瘤切除を行ってい るが，人工血管の選択と腹腔内止血操作をすばやく行う 必要がある。

CABG を施行した 症例中， IABP を必要とした症例 
は 28 例あったが，術前に合併症を有している症例であ り,この症例と術前㲹合併症のない症例との左室機能, 体外循環時間，大動脈遮断時間を比較検討して見たが， LVEDP 以外飞統計的有意差は認められなかった（図 1，
2).

体外循環時間の延長は，体外循環を V-A bypass と乙 て使用したための有意差であった。

\section{AIV-23 心筋梗塞の合併症に対する外科的療法}

—とくに心原性ショック並びに心室中隔穿孔例を中心として—

神戸大学 第 2 外科, 高砂市民病院*

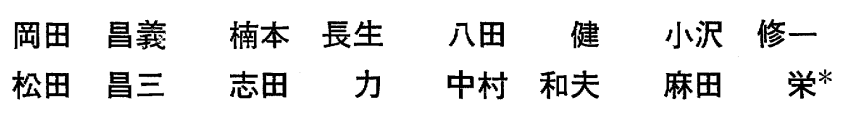

教室では昭和 44 年 1 月心筋梗塞発症 25 日目に infarctectomy を行って成功を収めて以来，心筋梗塞の合併 症に対して外科的療法を行った症例は 61 例である.こ れらの症例の内訳をみると，心筋梗塞後の心原性ショッ クに対して IABPを実施した 20 例, また完全房室ブロ ックに対して temporary pacemakingを施行した 20 例, さらに難治性不整脈あるいは塞栓症に対して infarctectomy p scartectomy を施行した各 1 例，僧帽弁逆流に対 して MVR を行った 3 例，心室中隔穿孔部閉鎖術と梗 塞部切除術を施行した 5 例敊よび IABP のみの 1 例, ま た aneurysmectomy と A-C bypass が同時に実施された 心室瘤の 3 例, さらに狭心痛とらっ血性心不全合併例飞 対して infarctectomy あるいは scartectomy に加兄て A-C bypass が施行された 7 例である.

今回，これらの症例中とくに予後が不良である心原性 ショック並びに心室中隔穿孔例を中心にわれわれの患者 管理，治療方針について報告する1,2).

\section{対象症例ならびに手術成績}

心笳梗塞の合併症に対して何らかの外科的療法を実施 したのは上述のごとく 61 例である. が，今回予後不良 な急性心筋梗塞後の心原性ショック 20 例と，心室中隔 穿孔 6 例を対象とした。

1）心原性ショック例に対するIABPの応用之成績 まず，心原性ショックの判定基準として，a）收縮期 血圧 $90 \mathrm{mmHg}$ 以下 (30 分以内に $30 \mathrm{mmHg}$ 以上の 急激な血圧低下のある場合), b) 尿量毎時 $20 \mathrm{~m} l$ 以下, c) 心係数 $2.0 \mathrm{l} / \mathrm{min} / \mathrm{m}^{2}$ 以下, d) 肺動脈楔入圧 $20 \mathrm{~mm}$ $\mathrm{Hg}$ 以上, e) 指趾の冷感, 循環不全などを採用し, こ

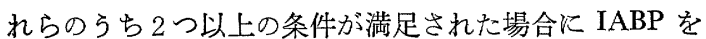
開始している2).

心筋梗塞後の心原性ショック 20 例に IABP を応用し， 8 例（40\%）に拈いて IABP からの離脱に成功を収め, 本法の有用性が認められた（表 1). 症例の性別は男 14 例，女 6 例であり，IABP の実施時間は 1 408 時間 (平均 65 時間) であった。 7 例では IABPを行いなが ら冠動脈造影を実施し, 手術適応のあった 3 例では緊急 手術が施行された。 IABP が適切に実施されるならば, 通常が $6 \sim 8$ 時間後には定常状態が維持され, 血圧の上 昇, 尿量の出現ないし堌加, 肺水腫の軽减, 末梢循環不 全などの改善がられる。しかし，これらの反応は心筋 梗塞の範囲之密接な関係がみられ，その範囲が左室自由 壁の $50 \%$ 以上に揖よぶと IABP の効果が期待されない 事実をわれわれは実験的並びに臨床面から確認した2). IABP の実施中はやや hypervolemic 管理し, 適宜 catecholamine の投与を行っているが，これらの操作に よっても血行動態の改善がえられない場合には IABP 実 施後少なくとも 12〜24 時間以内にアンギオを実施し, 適応が判明すれば直ちに緊急手術にふる切る方針をとっ ている2).

2）心室中隔穿孔に対する外科療法

現在をでに心筋梗塞後の心室中隔穿孔 6 例を経験した (表 2).このうち5 例に手術が実施されたが，3 例で は IABP にひき続き緊急手術が行われた。 5 例の手術例 中 3 例 $(50 \%)$ をIABP とタイミングよい緊急手術との 併用で救命した。これら 6 症例の梗塞発作から心室中隔 穿孔までの期間は $1 \sim 17$ 日（平均 5.7 日）であり, 穿 孔から手術までの期間は 13 時間，4，5，19 日，6 